\title{
THE INFLUENCE OF COMPENSATION, JOB SATISFACTION AND ORGANIZATIONAL COMMITMENT ON NURSES' TURNOVER INTENTION AT ACCREDITED HEALTH SERVICES OF EAST LOMBOK REGENCY, INDONESIA
}

\author{
Supriati Erni \\ Master Program of Management, University of Mataram, Indonesia \\ Agusdin, Furkan Lalu M. \\ Faculty Economic and Business, University of Mataram, Indonesia \\ *E-mail: ernisupriati77@gmail.com
}

\begin{abstract}
This study focused on a relationship between compensation, job satisfaction and organizational commitment on nurses' turnover intention at Accredited Health Services, East Lombok Regency. The study used census research as a quantitative research design. A sample of 154 non-civil servant service nurses was surveyed at Accredited Health services, East Lombok Regency, West Nusa Tenggara (Indonesia). The questionnaires were analyzed using path analysis by SPSS 16 . The results revealed that compensation and job satisfaction had no significant effect on turnover intention. Moreover, compensation and job satisfaction had a significant influence on organizational commitment. Meanwhile, organizational commitment had a significant effect on nurses' turnover intention at Accredited Health Services.
\end{abstract}

\section{KEY WORDS}

Compensation, job satisfaction, organizational commitment, turnover intention, nurse.

Turnover intention often faced by many organizations. Thus, the employee expected to have a new job as soon as possible (Ramlall in Sudita, 2015). The mismatch between work environment and competence, lower work allowance and social security are the main causes. Turnover intention is a tendency to stop working, seek another selected job (Mobley, 1986), and resignation resignation voluntarily or not voluntarily (Robbins \& Judge, 2015). An indication is the excessive of absence. Several studies revealed that the causes of turnover intention were lack of compensation (Paulus \& TJ, 2015), and job dissatisfaction (Maulana \& Cholil, 2016). According to Hasibuan (2012), compensation refers to money and others, either direct or indirect wage as a commendable given by the company.

A survey conducted by American Organization of Nurse Executive showed that the turnover level of Registered Nurse (RN) in 2000 was 21.3\%. Meanwhile, 13,9\% (Bernard Hodes Group, 2005) on 138 recruiters at health sector, and the vacancy rate at the hospital was $16.1 \%$ (Elizabeth, 2012). Lack of nurses causes poor service and fatigue. Turnover is a serious problem to the efficiency and effectiveness of health service. Survey research showed that the average absence rate of nurses at Accredited Health Services, East Lombok Regency was $4.57 \%$. According to Winaya (2011), the absence reporting was above $4-15 \%$. Moreover, it showed that the compensation was IDR 813,168 / month. The phenomenon of the high level of absence of nurses and the low compensation received by nurses made researchers interested in conducting this research. Thus, the study aims to analyze the effect of compensation, job satisfaction and organizational commitment on turnover intention toward non-civil servant service nurses at Accredited Health Services, East Lombok Regency.

\section{LITERATURE REVIEW}

According to Mobley (1986), turnover intention is a tendency to resign voluntarily from the previous job and move from one job others based on someone's choices. Mathis \& 
Jackson (2001) have explained that turnover intention is the process of leaving and replacing the job. It means that when an employee has resigned to his job, the other will replace his position. Robbins (2001) has stated that the resignation of someone from the organization (turnover) can be classified into 2 causes: (1) voluntary turnover is the employee's decision to resign voluntarily; (2) involuntary turnover is an employer's decision to commit uncontrollable work termination for the employee. Mobley et al (1978) and Harnoto (2002) have stated that the indicators were job seeker, resignation and scofflaw.

Compensation refers to salary or gift for employees (Dessler, 2007), it can be financial rewards and allowance (Simamora, 2004). The indicators are wage, salary, and incentive (Simamora, 2004; Luna-Arocas \& Camps, 2008). Research conducted by Liu (2012) and Long \& Perumal (2014) in the public sector showed that compensation had a negative effect on turnover intention, and these findings contradicted with Irbayuni (2012) which showed that compensation had a positive and significant effect on turnover intention. Furthermore, a case study at PT. Multi Abadi Sejahtera showed that compensation had a significant and positive influence on turnover intention (Paulus \& TJ, 2015).

Job satisfaction is employees' perceptions about the importance of working well for the organization (Luthans, 2006). Robbins \& Judge (2015) defined it as a general attitude which indicates the difference between the number of rewards received and the amount that should be received. Job satisfaction is measured using four indicators namely job satisfaction, salary satisfaction, satisfaction with the boss's attitude and coworkers (Roelen, Koopmans \& Groothoff, 2008).

Robbins (2006) in Putra \& Wibawa (2015) has stated that job satisfaction is negatively related to employee turnover. However, other factors such as the labor market, work opportunities, years of service are the obstacles in resignation. A study conducted at higher education (Alniacik et al., 2013) showed that job satisfaction was significantly negatively related to turnover intention. A study by Ozbag \& Ceyhun (2013) on Turkish Marine Pilots showed that job satisfaction had a negative effect on turnover intention. Weeks \& Sen (2016) indicated that job satisfaction increased, while turnover intention decreased. On the contrary, Paulus \& TJ (2015) indicated that job satisfaction had a significant and positive influence on turnover intention. Maulana \& Cholil (2016) also indicated that the higher level of job satisfaction not necessarily reducing the intention to move to other job. Meanwhile, a study from Risma (2018) showed that job satisfaction had a negative and no significant effect on turnover intention.

According to Mathis and Jackson (2001), organizational commitment is a trust level, an acceptance labor, and a desire to remain in organization. Choong et al. (2012) have stated that employee will have a strong desire to remain a certain member; he will also put a great effort into his work on behalf of the organization. Meyer and Allen (1991) explained three dimensions of organizational commitment; (1) affective commitment refers to emotional attachment, identification as well as the involvement of an employee in an organization, (2) continuance commitment deals with side-bets orientation concept emphasizes on a person's contribution that can be lost when the person leaves the organization, and (3) normative commitment indicates how far a person psychologically bound to be an employee based on loyalty, affection, warmth, ownership, pride, happiness, and soon.

Mowday et al. (1982) in Putra \& Wibawa (2015) have stated that employees with high organizational commitment will be more motivated and strive to achieve organizational goals. Meanwhile, high organizational commitment has a negative relationship with turnover level. Jehanzeb et al. (2013) and Yamazakia \& Petchdee (2015) found that organizational commitment had a negative and significant influence toward turnover intention in private sector and fisheries industry, Thailand. In addition, Saraih et al. (2017) found that organizational commitment had a negative and significant relationship toward it in a higher education, Malaysia. On the other hand, the finding showed that organizational commitment had a weak positive significant relationship on turnover intention in Nigerian Paramilitary (Falove, 2014). Moreover, Gamble \& Tian (2015) showed that affective and normative commitments were negatively affected turnover intention, and affective commitment had a 
positive influence on it. Then, normative and ongoing commitments did not have a significant effect on it, while affective commitment had a significant relationship on it (Sow, 2015).

Thus, the hypotheses are formulated as follows:

$\mathrm{H} 1$ : Compensation has a significant negative effect on turnover intention;

$\mathrm{H} 2$ : Job satisfaction has a significant negative effect on turnover intention;

H3: Compensation has a significant positive effect on organizational commitment;

$\mathrm{H} 4$ : Job satisfaction has a significant positive effect on organizational commitment;

H5: Organizational commitment has a significant negative effect on turnover intention.

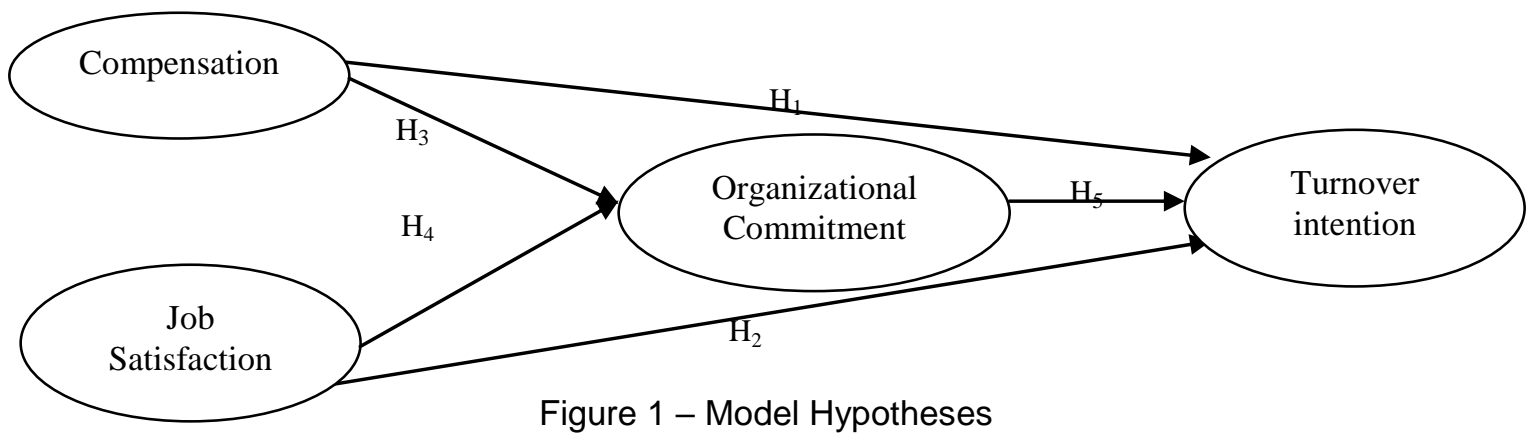

\section{METHODS OF RESEARCH}

This study used quantitative research design with a casual associative approach and it aims to determine the effect of independent variable on the dependent variable. It was conducted at Accredited Health Services, East Lombok Regency. The sample was 154 noncivil servant service nurses. The variables were turnover intention by Paulus \& TJ (2015) indicator, compensation by Paulus \& TJ (2015) and Luna-Arocas \& Camps (2008). Moreover, job satisfaction using indicator from Roelen et al. (2008) as well as organizational commitment using Allen \& Meyer (1997) in Risma (2018).

Each variable used a Likert scale, such as strongly agree, agree, partially disagree, disagree, and strongly disagree. The reliability test showed that Cronbach's Alpha was above 0,6 . It means that each item was reliable. Meanwhile, the validity used Pearson Product Moment correlation technique indicated that only job satisfaction variable was invalid, due to $r$-value is less than 0,3. Meanwhile, path analysis technique was used in this study.

\section{RESULTS AND DISCUSSION}

In accordance with the formulated hypothesis, in this study inferential statistical data analysis was measured using SPSS 16, starting from the normality test (KolmogorovSmirnov), calculating path coefficients and hypothesis testing (Riduwan and Kuncoro, 2013). Based on the Normality test data shows that all variables are normally distributed (Asymp value. Sig $>0.05$ ).

The normality test is used to test whether the regression model has a normal distribution or not (Ghozali, 2013). In this study, the normality test uses Kolmogorov-Smirnov (one sample K-S) with decision-making that is when p-value> 0.05 , then the data is normally distributed. Based on the normality test using Kolmogorov-Smirnov the following results are obtained:

Table 1 - One-Sampel Kolmogorov-Smirnov Test

\begin{tabular}{|c|c|c|c|c|}
\hline $\mathrm{n} / \mathrm{n}$ & Compensation & Job Satisfaction & Organizational Commitment & Turnover intention \\
\hline $\mathrm{N}$ & 154 & 154 & 154 & 154 \\
\hline Kolmogorov-Smornov Z & 1.154 & 1.123 & 1.210 & .914 \\
\hline Asymp. Sig. (2- tailed) & .139 & .113 & .140 & .374 \\
\hline
\end{tabular}

Source: Path Analysis. 
From the results in the Kolmogorov-Smirnov One-Sample table, the Asymp column. Sig. shows that the significance value for compensation, job satisfaction, organizational commitment and turnover intention is greater than 0.05 , it can be concluded that all variables are normally distributed. Kolmogorov_smirnov $Z$ column indicated that the smaller the distribution of the data, the more normal they would be. Path analysis technique was used to analyze the causal relationship among variables in order to find both direct and indirect effects simultaneously or independently of some exogenous for endogenous variables (Riduwan \& Kuncoro, 2013).

Table 2 - Result of Path analysis

\begin{tabular}{|c|c|c|c|c|c|}
\hline \multicolumn{2}{|r|}{ Hypothesis } & R-Square & Standardized Coefficient Beta & t-statistic & Conclusion \\
\hline $\mathrm{H} 1$ & Compensation $\rightarrow$ Turnover intention & .008 & .089 & 1.101 & Not significant \\
\hline $\mathrm{H} 2$ & Job Satisfaction $\rightarrow$ Turnover intention & .000 & -.010 & -.122 & Not significant \\
\hline $\mathrm{H} 3$ & Compensation $\rightarrow$ Organizational Commitment & .086 & .293 & 3.771 & Significant \\
\hline $\mathrm{H} 4$ & Job Satisfaction $\rightarrow$ Organizational Commitment & .182 & .427 & 5.825 & Significant \\
\hline H5 & Organizational Commitment $\rightarrow$ Turnover intention & .046 & -.213 & 2.693 & Significant \\
\hline
\end{tabular}

Source: Path analysis. * All significant at $p>0.000$.

The results showed that compensation had a positive value and did not significantly influence on turnover intention, which meant hypothesis 1 was rejected. The compensation size received by nurses did not affect their desires to move. Thus, it supported the finding from Irbayuni (2012) which indicated that compensation did not contribute to the desire to change the jobs. For instance, employees' expected incentives. Maulana \& Cholil (2016) found that salary was not the reason to move. Lum et al. (1998) explained that salary satisfaction was a feeling about how much salary should be received.

The result indicated that job satisfaction had no significant effect on turnover intention, it could be said that hypothesis 2 was rejected. The higher the level of job satisfaction, it was not necessarily reducing the desire to resign. This happened because of salary satisfaction. Unlike the study, Alniacik et al. (2013) and Ozbag \& Ceyhun (2013) found that job satisfaction had a significant negative effect on turnover intention. However, this study agreed with Maulana \& Cholil (2016) and Risma (2018) shows that job satisfaction had no significant effect on turnover intention.

The third hypothesis showed a positive and significant effect, which meant hypothesis 3 was accepted. The significant correlation between compensation and organizational commitment caused nurses to commit continually to organization. Commitment increased, when a nurse had responsibility and commitment to have self development. Thus, this study supported the finding from Nawab \& Bhatti (2011) and Budiningsih et al. (2017), which indicated that there was positive significant correlation between compensation and organizational commitment.

The hypothesis test between job satisfaction and organizational commitment showed positive and significant effect. Thus, hypothesis 4 was accepted. Working indicated how satisfied an employee and it affected organizational commitment. Responsibility made work easier. Moreover, a nurse would have more opportunity to learn new things, responsibility, and challenge to the field of work. When a nurse worked sincerity and responsibility, it would increase organizational commitment. This hypothesis supported the findings from Mohammad \& Eleswed (2013), Thabane et al. (2017) and Cherian et al. (2018).

The hypothesis test result between organizational and turnover intention had a negative and significant effect. Thus, hypothesis 5 was accepted. An employee would work continually, due to he agreed, felt useful, and competent to remain in organization. He also felt comfortable, safe, and got benefits. Thus, nurses had homey feel so that turnover intention became low. The findings from Jehanzeb et al. (2013), Yamazakia \& Petchdee (2015) and Saraih et al. (2017) showed that organizational commitment had a negative and significant effect on turnover intention. 


\section{CONCLUSION}

To conclude, compensation had no significant positive effect on turnover intention, and compensation had a significant positive effect on organizational commitment. Then, job satisfaction had a significant positive effect on organizational commitment, while organizational commitment had a significant negative effect on turnover intention. The research limitations focused on three variables namely compensation, job satisfaction, and organizational commitment. Moreover, the sample was taken from non-civil service nurses at Accredited Health Services, East Lombok Regency. Thus, the result of the study may not be applicable to other group other than the ones initially tested.

\section{REFERENCES}

1. Alniacik, E., Alniacik, U., Erat, S., \& Akcin, K. (2013). Does person-organization fit moderate the effects of affective commitment and job satisfaction on turnover intentions. Procedia-Social and Behavioral Sciences, 99, 274-281. doi: 10.1016/j.sbspro.2013.10.495.

2. Budiningsih, S., Warso, M. M., \& Yulianeu. (2017). Hubungan Pengembangan Karir dan Kompensasi Terhadap Kepuasan Kerja dan Implikasinya Pada Komitmen Organisasional PT. Pertani (Persero), Wilayah Jateng \& DIY. Journal of Management, 3 (3), 2502-2519.

3. Cherian, S., Alkhatib, A. J., \& Anggarawal, M. (2018). Relationship Between Organizational Commitment and Job Satisfaction of Nurses In Dubai Hospital. Journal of Advances in Social Science and Humanities, 4 (1), 36373-36400. doi: 10.15520/jassa41276.

4. Choong, Y. O., Wong, K.L., \& Lau, T. C. (2012). Organizational Commitment: An Empirical Investigation on the Academician of Malaysian Private Universities. Business and Economics Research Journal, 3 (2), 51-64. ISSN: 1309-2448.

5. Dessler, G. (2007). Manajemen Sumber Daya Manusia Edisi Bahasa Indonesia Jilid 1 (Edisi 10). Jakarta. PT Indeks.

6. Elizabeth, M. L. (2012). Hubungan Antara Pelanggaran Kontrak Psikologis Menurut Perawat Dengan Intention to Quit Dan Kepuasan Kerja Perawat Rumah Sakit X. Tesis. Magister Administrasi Universitas Indonesia. Diunduh 19 Januari 2018 dari http://www.lontar.ui.ac.id.

7. Faloye, D. O. (2014). Organizational Commitmen and Turnover Intentions: Evidence from Nigerian Paramilitary Organization. International Journal of Business and Economic Development Issues, 2 (3), 23-34.

8. Gamble, J., \& Tian, A. W. (2015). Intra-national in organizational commitment: Evidence from the Chinese context. The International Journal of Business and Economic Development, 7 (26), 948-970. doi: 10.1080/09585192.7222122.

9. Ghozali, I. (2013). Aplikasi Analisis Multivariate dengan Program IBM SPSS Semarang: Badan Penerbit Universitas Diponegoro.

10. Harnoto. (2002). Manajemen Sumber Daya Manusia. Edisi Kedua. Jakarta: PT. Prehallindo.

11. Hasibuan, M. (2012). Manajemen Sumber Daya Manusia. Jakarta: PT Bumi Aksara.

12. Irbayuni, S. (2012). Pengaruh Kompensasi, Kepuasan Kerja dan Komitmen Organisasi terhadap keinginan untuk Pindah Kerja pada PT. Surya Sumber Daya Energi Surabaya. Jurnal NeO-Bis, 6 (1), 1-12.

13. Jehanzeb, K., Rasheed, A., \& Rasheed, M. F. (2013). Organizational Commitment and Turnover Intentions: Impact of Employee's Training in Private Sector of Saudi Arabia. International Journal of Business and Management, 8 (8), 79-90. doi:10.5539/ijbm.v8n8p79.

14. Liu, S. (2012). The influences of school climate and teacher compensation on teachers' turnover intention in China. Educational Psychology, 32 (5), 553-569. https://doi.org/10.1080/01443410.2012.691074. 
15. Long, C. S., \& Perumal, P. (2014). Examining the Impact Of Human Resource Management Practices On Employees' Turnover Intention. International Journal of Business and Society, 15 (1), 111-126.

16. Lum, L., Kervin, J., \& Clark, K. (1998). Explaining nursing turnover intent: Job satisfaction, pay satisfaction or organizational commitment. Journal of Organizational Behavior, 24, 543-565.

17. Luna-Arocas, R., \& Camps, J. (2008). A model of high performance work practices and turnover intentions. Personnel Review, 37 (1), 26-46. doi:10.1108/00483480810839950

18. Luthans, F. (2006). Perilaku Organisasi. Yogyakarta. ANDI.

19. Mathis, R. L \& Jackson, J.J. (2001). Manajemen Sumber Daya Manusia.Terjemahan Buku 1. Jakarta: Salemba Empat.

20. Maulana, A. C., \& Cholil, M. (2016). Praktik Manajemen Sumber Daya Manusia pada Kepuasan Kerja, Komitmen karyawan dn Niat Berpindah. Jurnal Bisnis dan Manajemen, 16 (1), 1-24.

21. Meyer, J. P., \& Allen, N. J. (1991). A Three Compenent Conceptualization of Organizational Commitment. Human Resources Management Review, 1 (1), 61-89. ISSN: 1053-4822.

22. Mobley, W.H., Horner, S.O. \& Hollingsworth, A.T. (1978). An Evaluation of Precursors of Hospital Employee Turnover. Journal of Applied Psychology, 63 (4), 408-414.

23. Mobley, W.H. (1986). Pergantian Karyawan: Sebab Akibat dan Pengendaliannya (Terjemahan Iman). Jakarta: PT Pustaka Binaman Pressindo.

24. Mohammed, F., \& Eleswed, M. (2013). Job satisfaction and organizational commitment: A correlational study in Bahrain. International Journal of Business, 3 (5), 43-53.

25. Nawab, S., \& Bhatti, K. K. (2011). Influence of Employee Compensation on Organizational Commitment and Job Satisfaction: A Case of Educational Sector of Pakistan. International Journal of Business and Social Science, 2 (8), 25-32.

26. Özbag, G. K., \& Ceyhun, G. Ç. (2013). Does Job Satisfaction Mediate The Relationship Between WorkFamily Conflict And Turnover? A Study of Turkish Marine Pilots. ProcediaSocial and Behavioral Sciences, 140, 643-649. doi: 10.1016/j.sbspro.2014.04.485

27. Paulus, E., \& Tj, W. H. (2015). Pengaruh Kompensasi dan Kepuasan Kerja Terhadap Turover Intention Karyawan (Studi Kasus Pada PT. Multi Abadi Sejahtera). Jurnal IImiah Manajemen Bisnis Issue, 15 (2), 81-97.

28. Putra, I. G. A. G. E. M., \& Wibawa, I. M. A. (2015). Pengaruh Kepuasan Kerja terhadap Turnover Intention dengan Komitmen Orgaisasional sebagai Variabel Intervening pada PT. Autobagus Rent Car Bali. Manajemen Unud, Issue, VI (4), 11-18.

29. Ridwuan dan Kuncoro, E. A. (2012). Cara menggunakan dan Memakai Path Analysis (Analisis Jalur): Alfabeta.

30. Risma, N. (2018). Peran Mediasi Komitmen Organisasional pada Pengaruh PersonOrganization Fit dan Kepuasan Kerja Terhadap Turnover Intention (Studi pada Karyawan Marketing Funding PT. Bank NTB), Tesis. Magister Manajemen Universitas Mataram.

31. Robbins, S. P. (2001). Organizational Behavior, 9th Ed. Upper Saddle RiverNew Jersey 07458, Prentice Hall International.

32. Robbins, S. P., \& Judge, T. A (2015). Perilaku Organisasi (Organizational Behavior) (16 ed.). Jakarta: Salemba Empat.

33. Roelen, C. A. M., Koopmans, P. C., \& Groothoff, J. W. (2008). Which work factors determine job satisfaction?. Work, 30, 433-439.

34. Saraih, U. N., Aris, A. Z. Z., Karim, K. M., Samah, I. H. Z., Sa'aban, S., \& Mutalib, S.A. (2017). Relationship Between Organizational Commitment, OCB, Organizational Justice and Turnover Intention: Evidence from Educational Institution in Malaysia. Rev. Integr. Bus. Econ. Res, 6 (2), 64-77.

35. Simamora, H. (2004). Manajemen Sumber Daya Manusia, Edisi Ketiga. Yogyakarta. STIE YPKN.

36. Sow, M. T. (2015). Relationship between Organizational Commitment and Turnover Intentions among Healthcare Internal Auditors. Dissertaions. College of Management and 
Technology. Walden University. Diunduh 08 April 2018 dari http://scholarwork.waldenu.edu/dissertations.

37. Sudita, I. N. (2015). Pengaruh Kepuasan Gaji, Kepuasan Kerja, Dan Komitmen Organisasional Terhadap Turnover Intention (Studi Kasus Pada Bidan Praktek Swasta Di Kabupaten Sleman). Efektif Journal Bisnis dan Ekonomi, 6 (1), 89-99.

38. Thabane, L., Radebe, P., \& Dhurup, M. (2017). The Effect of Job Saridfaction on the Organisational Commitmen of Administrators. Journal of Economics and Behavioral Studies, 9 (6), 188-198.

39. Weeks, K., \& Sen, K. (2016). The Moderating Effect Satisfaction has on Turnover Intentions and Organizational Citizenship Behavior. Journal of Management Policy and Practice, 17 (2), 78-84.

40. Winaya, K. (2011). Manajemen Sumber Daya Manusia. Universitas Udayana.

41. Yamazakia, Y., \& Petchdee, S. (2015). Turnover Intention, Organizational Commitment, and Specific Job Satisfaction among Production Employees in Thailand. Journal of Business and Management, 4 (4), 23-38. 